\title{
River Health Evaluation Based on the Fuzzy Matter-Element Extension Assessment Model
}

\author{
Wei Xü ${ }^{1 *}$, Zengchuan Dong ${ }^{1}$, Zhenchun $\mathrm{Hao}^{2}$, Dayong Li ${ }^{1}$, Li Ren ${ }^{1,2}$ \\ ${ }^{1}$ College of Hydrology and Water Resources, Hohai University, \\ Nanjing 210098, China \\ ${ }^{2}$ State Key Laboratory of Hydrology-Water Resources and Hydraulic Engineering, Hohai University, \\ Nanjing 210098, China
}

Received: 8 November 2016

Accepted: 25 November 2016

\begin{abstract}
The measured values of river health indexes that are not necessarily in the same range of a certain health grade level cause the problem of how to classify the actual status of river health. To solve such incompatibility and evaluate the health condition of a river ecosystem objectively we can use the river health integrated index $(R H I)$, which was determined by the fuzzy matter-element extension assessment model (FMEAM). FMEAM was established by combining the fuzzy matter-element extension assessment method with the proposed aggregative index system. By employing the model above, as well as data from the 1980s, 1990s, and 2000s, we evaluated the health state of the Luanhe River. The results showed that the Luanhe River was in a sub-healthy state in the 1980s and in an unhealthy state in the 1990s and 2000s. The reasons leading to the Luanhe River's health degradation have been analyzed. Among them, water conservation projects' building and operations are the major influence factors. Waste water emissions, the expansion of urban built-up areas, over exploitation of groundwater, and other unreasonable human activities also intensified the river ecosystem degradation. Finally, countermeasures for the ecological restoration and protection of the river were put forward.
\end{abstract}

Keywords: river ecosystem, fuzzy matter-element extension assessment model, health evaluation, degradation reasons, Luanhe River

\section{Introduction}

Society benefits immeasurably from rivers [1], and more and more water conservancy projects have improved more and more people's lives - especially regarding aspects of flood control and water supply in developing

*e-mail: xuwill@hhu.edu.cn and undeveloped countries [2]. But with the rapid development of the economy, increasing human activities, and climate changes, river ecosystem health degrades day by day in many regions, represent by the sharp imbalance between water resource supply and demand, natural wetland shrinkage, serious river contamination, deductions in estuary runoff, and the disappearance of endemic fish, etc., all influence the sustainable development of nature, the economy, and society [3-9]. 
Due to serious river ecosystem degradation, river assessment and watershed management have become research hotspots in recent years [10-13]. The assessment of river health originated from water quality evaluation. In the $1980 \mathrm{~s}$, the main points of river protection started to change from water quality conservation to comprehensive management and restoration of a river ecosystem. And two important biological methods for river health assessment appeared: (a) the Index of Biotical Integrity (IBI) [14] and (b) the River Invertebrate Prediction and Classification System (RIVPACS) [15]. Besides, based on the concept of IBI, the Algae Abundance Index (AAI) [16] and the Specific Polluosensitivity Index (IPS) [17] come up later.

Currently, two methods for river health assessment are generally accepted, one of which is biological monitoring using indicative species as IBI, while the other is the aggregate indicator method covering physical, chemical, biological, and socio-economic information [18], and among which the most well known is the Integrated Habitat Assessment System (IHAS) in South Africa [19].

But river health is not a static or changeless concept. It is a dynamic and relative concept to different regions in different stages of river life [18]. A successful assessment method in one region, including its evaluating indicators and their standards, may be not appropriate for another region. Nowadays, developed countries pay a lot of attention to protect a river's health, as they have experienced industrialization stage and have come to realize the importance of river ecosystem health. While the developing and the least developed countries have to exploit their rivers' and lakes' resources to feed a growing population and to promote social progress - especially agricultural and industrial development, resulting in their stakeholders and policy makers laying emphasis not only on rivers' natural characteristics, but also on their function for the service and well-being of the population. So their understandings about river health, their assessment methods (which include the chosen index system), and the weight and the assessment model may be different between even two similar regions or rivers.

And with the development of science and technology and the human understanding of the world, how river health changes is more important to the stakeholders and policy makers, and how to maintain river ecosystem health permanently has received more attention. Ecological flow, water quality, and aquatic life are the three most important aspects for river ecosystems. And more than 200 methods have been proposed to analyze them respectively [20-26]. So far, there is not an appropriate comprehensive index for evaluating the river health state.

As one of the biggest developing countries in the world, China has the largest population and a surprising economic growth rate in the last 30 years. However, China's economic success has come along with serious river problems caused by human activity and climate change [27]. The Luanhe River is located in northern China, one of the most densely populated areas, and it is the drinking water source of Tianjin and Tangshan, two important cities in China. In recent decades the runoff of the Luanhe River deceased significantly and water quality worsened obviously, due to climate change and unreasonable development and utilization. And these river-related problems have seriously threatened the water supply security, food security, and ecological security of the basin. In 2010 the river health index system was divided into five criterion layers: hydrology and water resources, physical structure, water quality, aquatic life, and social service function in the country's major rivers and lakes health assessment work by China's Ministry of Water Resources. And this integrated assessment method has become a widely used assessment method for river health in China. However, for the measured values of river health indexes that are not necessarily in the same range of a certain health grade level, the problem becomes how to classify the actual status of river health. To solve such incompatibility and conflicts, this paper proposes the concept of the River Health Integrated Index (RHI), a comprehensive index for river health status calculated by the fuzzy matter-element extension assessment model (FMEAM). Luanhe River has been selected as a case study, and RHIs were calculated for the past three decades. Accordingly, the reasons for Luanhe health variations were discussed and some countermeasures were put forward. This investigation and assessment of river health may provide a vital basis for integrated river management and restoration.

\section{Material and Methods}

\section{Study Area Background}

The Luanhe originates in the Inner Mongolian plateau of northern China and flows southeastward $888 \mathrm{~km}$ through three provinces (Inner Mongolia, Liaoning, and Hebei) before emptying into the Bohai Sea (Fig. 1). The basin area is $44,750 \mathrm{~km}^{2}$, among which mountains account for $98.2 \%\left(43,940 \mathrm{~km}^{2}\right)$ and plains account for the rest $1.8 \%\left(810 \mathrm{~km}^{2}\right)$.

Luanhe runoff is relatively large among rivers in northern China, and its mean annual natural runoff is over $4 \times 10^{9} \mathrm{~m}^{3}$. However, since the completion and operation of Panjiakou, Daheiting, and Taolinkou reservoirs and other large-scale major water conservancy projects in the river's main stream and tributaries, the river has become a water resource area of Tianjin and Tangshan - two large cities near the basin's eastern part. The development and utilization intensity of water resources in this basin is also continuously increasing with the fast-growing water demand of the regional economy. With the building of these reservoir dams and the operating of these inter-basin water diversion projects in the Luanhe, great changes have occurred in the flow and sediment processes of downstream channels. These projects have damaged the physical structures of channels, causing the degeneration of river ecological functions and biodiversity loss, and also have led to the erosion and recession of the modern Luanhe delta shoreline $[2,28]$. In addition, wastewater emissions 


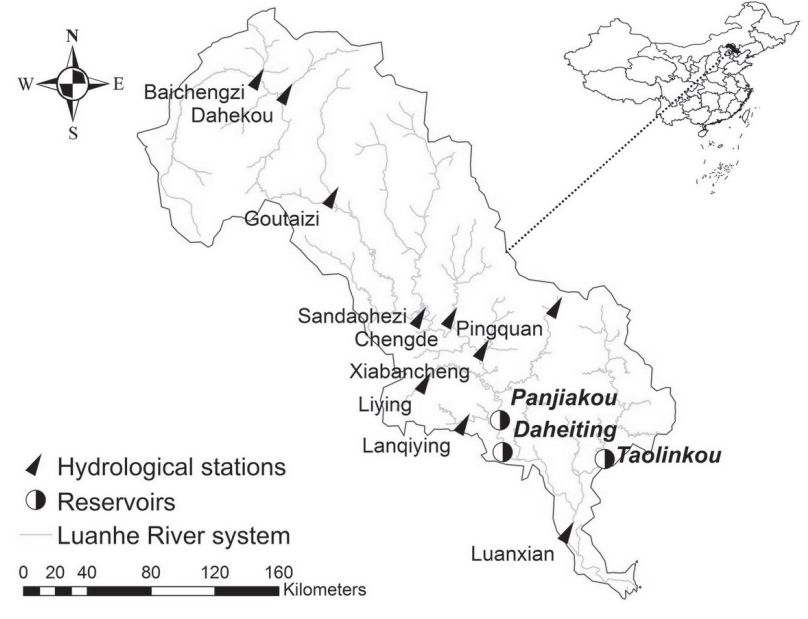

Fig. 1. Location of the Luanhe River.

have reached $4.5 \times 10^{8}$ tons per year now, which is twice that of the 1980s. The midstream and downstream of the Luanhe have been seriously polluted, which aggravates river ecosystem degradation. Besides, the midstream and upstream area of the Luanhe River Basin is also a key area for soil and water conservation. Planting trees and grass has improved the ecological environment of the basin. But at the same time it has become a factor leading to decreasing runoff. Consequently, comprehensive river health assessment is particularly important in the context of more prominent conflict between ecology and development, and may provide useful information for stakeholders and policy makers when conducting integrated management of the river, especially along ecological and restorative lines.

\section{Methods}

The ultimate goal of river ecosystem health assessment is to manage the river more effectively. This study intends to combine the fuzzy matter-element extension assessment method with the proposed assessment index system to establish FMEAM to get $R H I$.

\section{Assessment Index System and Its Standard and Weight}

Factors that affect river health are very complex. Hundreds of indicators can characterize the health state of a river, which covers physical, chemical, biological, and socio-economic information [18, 29-33]. In 2010 China's Ministry of Water Resources established five criteria - the river health index system - for assessing the the country's major rivers and lakes: hydrology and water resources, physical structure, water quality, aquatic life, and social service function. In 2014 Liu constructed an integrated index system for Luanhe River's health assessment, which was divided into river morphology, water quantity, water quality, aquatic life, river habitat, flood control, and water supply [33]. But in Liu's system, she had not considered the fact that the construction and operation of large-scale reservoirs along the river had altered its sediment regime.

A reasonable index system must be built by analyzing the river's characteristics and functions. So this paper establishes the Luanhe's index system based on its own characteristics and the ministry's index system. The concrete considerations are as follows:

1) As far as possible to select the quantitative indexes.

2) Some biological indexes which do not have long series of monitoring values are not selected.

3) The Luanhe does not have shipping and aquatic products, so these indexes are not considered.

4) Add some indexes such as vegetation index, rates of water loss and soil erosion, and wetland preservation rate, which are not included in the ministry's index system.

Because the middle and upper reaches of the Luanhe are a key area of soil and water conservation, the soil and water conservation project can directly affect the amount of water and sediment of the River. There are also many wetlands distributed among the sources and estuaries of the Luanhe, and these wetlands are important natural resources that play a key role in maintaining the river's ecological balance.

The index system of Luanhe River ecosystem health can be divided in two parts: its natural function subsystem (S1) and its social service function subsystem (S2). The natural function subsystem includes five items: (a) hydrology and water resources (B1), (b) physical structure (B2), (c) water quality characteristics (B3), (d) aquatic life characteristics (B4), and (e) riparian zone characteristics (B5); the social service function subsystem includes (a) flood control (B6) and (b) water supply (B7). From the point of view of the index layer, hydrology and water resources include: (a) estuary runoff index (C1), (b) minimum ecological flow guarantee rate (C2), (c) annual runoff change rate (C3), and (d) sediment transport change rate (C4); physical structure includes (a) lateral stability index (C5) and (b) longitudinal connectivity index (C6); water quality characteristics include water quality compliance index (C7); aquatic life characteristics includes phytoplankton Shannon index (C8); riparian zone characteristics include (a) vegetation index (C9), (b) water loss and soil erosion rate (C10), and (c) wetland preservation rate $(\mathrm{C} 11)$; and flood control guarantee rate $(\mathrm{C} 12)$ and water supply guarantee rate $(\mathrm{C} 13)$ belong to flood control and water supply, respectively (Table 1). Among these 13 indexes, C3, C4, C5, C6, and C10 belong to cost type while the other eight indexes belong to benefit type. And the benefit type indicates that when the index value is larger, the river ecosystem is healthier, while the cost type indicates that when the index value is smaller, the river ecosystem is healthier.

In this index system, the weights of each subsystem, each item, and each index were also given in Table 1 . And these weights were determined using the expert evaluation method [34]. The steps of expert evaluation method are as follows: 
Table 1. Index system of river ecosystem health.

\begin{tabular}{|c|c|c|c|c|c|}
\hline Subsystems & Weight & Items & Weight & Index Layer & Weight \\
\hline \multirow{11}{*}{ Natural function (S1) } & \multirow{11}{*}{0.700} & \multirow{4}{*}{$\begin{array}{c}\text { Hydrology and } \\
\text { water resources } \\
\text { (B1) }\end{array}$} & \multirow{4}{*}{0.230} & Estuary runoff index $(\mathrm{C} 1)$ & 0.200 \\
\hline & & & & Minimum ecological flow guarantee rate $(\mathrm{C} 2)$ & 0.300 \\
\hline & & & & Annual runoff change rate $(\mathrm{C} 3)$ & 0.250 \\
\hline & & & & Sediment transport change rate $(\mathrm{C} 4)$ & 0.250 \\
\hline & & \multirow{2}{*}{$\begin{array}{l}\text { Physical structure } \\
\text { (B2) }\end{array}$} & \multirow{2}{*}{0.140} & Lateral stability index (C5) & 0.350 \\
\hline & & & & Longitudinal connectivity index (C6) & 0.650 \\
\hline & & Water quality (B3) & 0.220 & Water quality compliance rate (C7) & 1.000 \\
\hline & & Aquatic life (B4) & 0.250 & Phytoplankton Shannon index (C8) & 1.000 \\
\hline & & \multirow{3}{*}{$\begin{array}{l}\text { Riparian zone } \\
\text { (B5) }\end{array}$} & \multirow{3}{*}{0.160} & Vegetation index (C9) & 0.200 \\
\hline & & & & Water loss and soil erosion rate $(\mathrm{C} 10)$ & 0.400 \\
\hline & & & & Wetland preservation rate $(\mathrm{C} 11)$ & 0.400 \\
\hline \multirow{2}{*}{$\begin{array}{l}\text { Social service function } \\
\qquad(\mathrm{S} 2)\end{array}$} & \multirow{2}{*}{0.300} & Flood control (B6) & 0.400 & Flood control guarantee rate $(\mathrm{C} 12)$ & 1.000 \\
\hline & & Water supply (B7) & 0.600 & Water supply guarantee rate $(\mathrm{C} 13)$ & 1.000 \\
\hline
\end{tabular}

1) Determine the list of six experts who must be very familiar with the characteristics of the Luanhe and even performed research on it.

2) The sum of the index weights of the same item, the sum of the item weights of the same subsystem, and the sum of subsystem weights must be 1 . Select the indexes of item B2 as an example. It has two indexes: C5 and C6. If the weight of C5 is scored as 0.45, then the weight of C6 will be 0.55 . Make sure all experts have understood the rules of scoring.

3) Give each of them a scoring table and tell them they can revise their scoring before final submission.

4) Calculate the average weight, which will be the final weight of each subsystem, item, and index.
As river health is a dynamic and relative concept, different people have their own opinions for various considerations. Table 2 assesses the standard of the index system for the Luanhe based on many existing assessment standards, especially Liu's and the ministry's [18, 33]. And the health states of all indexes were divided into five grades as follows: (a) very sick, (b) sick, (c) unhealthy, (d) sub-healthy, and (e) healthy.

\section{Fuzzy Matter-Element Extension Assessment Method}

Extenics was founded in 1983 by Chinese researcher Cai Wen [35]. For the measured values of the river

Table 2. Five-grade health assessment standard.

\begin{tabular}{|c|c|c|c|c|c|}
\hline Index Layer & Very sick & Sick & Unhealthy & Sub-healthy & Healthy \\
\hline Estuary runoff index (\%) & $<15$ & {$[15,30)$} & {$[30,50)$} & {$[50,70)$} & $\geq 70$ \\
\hline Minimum ecological flow guarantee rate (\%) & $<20$ & {$[20,40)$} & {$[40,60)$} & {$[60,80)$} & $\geq 80$ \\
\hline Annual runoff change rate (\%) & $>40$ & $(20,40]$ & $(10,20]$ & $(5,10]$ & $\leq 5$ \\
\hline Sediment transport change rate (\%) & $>60$ & $(40,60]$ & $(20,40]$ & $(5,20]$ & $\leq 5$ \\
\hline Lateral stability index & $>0.8$ & $(0.6,0.8]$ & $(0.4,0.6]$ & $(0.2,0.4]$ & $\leq 0.2$ \\
\hline Longitudinal connectivity index & $>0.8$ & $(0.6,0.8]$ & $(0.4,0.6]$ & $(0.2,0.4]$ & $\leq 0.2$ \\
\hline Water quality compliance index (\%) & $<25$ & {$[25,50)$} & {$[50,70)$} & {$[70,80)$} & $\geq 80$ \\
\hline Phytoplankton Shannon index & $<0.5$ & {$[0.5,1.5)$} & {$[1.5,2.0)$} & {$[2.0,3.0)$} & $\geq 3.0$ \\
\hline Vegetation index (\%) & $<10$ & {$[10,25)$} & {$[25,50)$} & {$[50,70)$} & $\geq 70$ \\
\hline Water loss and soil erosion rate (\%) & $>60$ & $(40,60]$ & $(25,40]$ & $(15,25]$ & $\leq 15$ \\
\hline Wetland preservation rate (\%) & $<20$ & {$[20,40)$} & {$[40,60)$} & {$[60,80)$} & $\geq 80$ \\
\hline Flood control guarantee rate (\%) & $<40$ & {$[40,60)$} & {$[60,70)$} & {$[70,80)$} & $\geq 80$ \\
\hline Water supply guarantee rate (\%) & $<30$ & {$[30,50)$} & {$[50,70)$} & {$[70,90)$} & $\geq 90$ \\
\hline
\end{tabular}


health indexes are not necessarily in the same range of a certain health grade level which is shown in Table 2, the problem of how to classify the actual state of river health is produced. To solve such incompatibility and conflicts, extenics is used with the fuzzy matter-element concept by calculating its relation degree. And the health state of the river will be diagnosed by the relation degree. Steps of the fuzzy matter-element extension assessment method are as follows:

(a) Determine the matter-element matrix of river ecological health and the classical domain.

The core content of extension theory is a ternary combination set, $\boldsymbol{R}=(\boldsymbol{N}, \boldsymbol{C}, \boldsymbol{X})$, which comprises object $(\boldsymbol{N})$ and the object's characteristics $(\boldsymbol{C})$, and measures the characteristics $(\boldsymbol{X})$ [29]. Suppose that an object $N$ is described by $\mathrm{n}$ characteristics $\left[c_{1}, c_{2} \ldots, c_{n}\right]$ with corresponding measures $\left[x_{1}, x_{2} \ldots, x_{n}\right]$, and the n-dimensional mixed-element $\boldsymbol{R}$ can be expressed in matrix form:

$$
\boldsymbol{R}=(\boldsymbol{N}, \boldsymbol{C}, \boldsymbol{X})=\left[\begin{array}{ccc} 
& c_{1} & x_{1} \\
& c_{2} & x_{2} \\
& \vdots & \vdots \\
& c_{n} & x_{n}
\end{array}\right]
$$

Regarding the health state of the Luanhe as matterelement $N$, there are five indexes in Table 1 belonging to cost type, convert these indexes value and thresholds value of each health level before determining the classical domain. Conversion formulas are as follows:

Suppose $x$ is the index value or threshold value for a certain health level in Table 1 .

When the index is $\mathrm{C} 3$ or $\mathrm{C} 4$ or $\mathrm{C} 10$ :

$$
x^{\prime}=100-x
$$

When the index is $\mathrm{C} 5$ or $\mathrm{C} 6$ :

$$
x^{\prime}=1-x
$$

Record the new threshold value between "very sick" and "sick" and the new threshold value between "healthy" and "sub-healthy" in Table 1 as $a_{i}$ and $b_{i}(i=1,2, \ldots, 13)$ in turn, respectively.

$$
\boldsymbol{R}=(\boldsymbol{N}, \boldsymbol{C}, \boldsymbol{X})=\left[\begin{array}{ccc} 
& c_{1} & \left\langle a_{1}, b_{1}\right\rangle \\
& c_{2} & \left\langle a_{2}, b_{2}\right\rangle \\
\boldsymbol{N} & \vdots & \vdots \\
& c_{n} & \left\langle a_{13}, b_{13}\right\rangle
\end{array}\right]
$$

(b) Determine matter-element $\boldsymbol{N}_{0}$ for assessment:

$$
\boldsymbol{R}=\left[\begin{array}{ccc} 
& c_{1} & x_{1} \\
& c_{2} & x_{2} \\
\boldsymbol{N}_{0} & \vdots & \vdots \\
& c_{13} & x_{13}
\end{array}\right]
$$

$\ldots$ where $\boldsymbol{N}_{0}$ is the evaluation object and $x_{i}$ is the converted value of $c_{i}$.

(c) Calculate relation degree:

Suppose $x_{i}^{(a)}=a_{i}$ and $x_{i}^{(b)}=b_{i}$ and they are the left and right base point of index set $c_{i}$, respectively. The calculation formula of relation degree is as follows:

$$
m_{i j}=\left\{\begin{array}{cc}
1 & x_{i} \geq x_{i}^{(b)} \\
\frac{x_{i}-x_{i}^{(a)}}{x_{i}^{(b)}-x_{i}^{(a)}} & x_{i}^{(a)}<x_{i}<x_{i}^{(b)} \\
0 & x_{i} \leq x_{i}^{(a)}
\end{array}\right.
$$

Then relation degree matrix $M_{k}$ can be found:

$$
M_{k}=\left[\begin{array}{c}
m_{1} \\
m_{2} \\
\vdots \\
m_{13}
\end{array}\right]
$$

(d) Calculate $R H I$ :

$R H I$ is calculated through relation degree matrix and the weights of these index layer by layer:

$$
\begin{gathered}
R H I_{N}=W_{N}^{T} \bullet M_{N} \\
R H I_{S}=W_{S}^{T} \bullet M_{S} \\
R H I=w_{N} \bullet R H I_{N}+w_{S} \bullet R H I_{S}
\end{gathered}
$$

...where $W_{N}$ is the index weight matrix of natural function subsystem, $M_{N}$ is the indexes relation degree matrix of natural function subsystem, and $R H I_{N}$ is the natural function subsystem integrated index. Where $W_{S}$ is the index weight matrix of social service function subsystem, $M_{S}$ is the index relation degree matrix of social service function subsystem, $R H I_{S}$ is the social service function subsystem integrated index, $w_{N}$ is the weight of natural function subsystem, $w_{S}$ is the weight of social service function subsystem, and $R H I$ is the river health integrated index.

\section{Criterion of RHI}

Put the converted health level threshold value of each index into the fuzzy matter-element assessment method to learn the health state threshold of RHI (Table 3). The river health state can also be divided into five grades: (a) very sick, (b) sick, (c) unhealthy, (d) sub-healthy, and (e) healthy. 
Table 3. Classification of river ecosystem health.

\begin{tabular}{|c|c|c|c|c|c|}
\hline Assessment level & Very sick & Sick & Unhealthy & Sub-healthy & Healthy \\
\hline RHI & 0 & $(0,0.396)$ & {$[0.396,0.702)$} & {$[0.702,1)$} & 1 \\
\hline
\end{tabular}

\section{Data Sources}

Sources of data used in this paper are as follows:

\section{Flow Data}

Daily time series of flow discharge $\left(\mathrm{m}^{3} / \mathrm{s}\right)$ data from 1956 to 2010 at Luanxian, Chengde, Baichengzi, Dahekou, Sandaohezi, Xiabancheng, Liying, Pingquan, Lanqiying, Taolinkou Reservoir, Daheiting Reservoir, and Goutaizi (Fig. 1) were collected from the Haihe River Water Resources Commission (HWRC). The homogeneity and reliability of the hydrological data have been checked and firmly controlled by HWRC before their release.

\section{Sediment Data}

Monthly time series of suspended sediment concentration $\left(\mathrm{kg} / \mathrm{m}^{3}\right)$ data from 1956 to 2010 at Luanxian, Chengde, Sandaohezi, Liying, Taolinkou, and Goutaizi (Fig. 1) were collected from HWRC. The homogeneity and reliability of the hydrological data have been checked and firmly controlled by HWRC before their release.

Table 4. Index values for each period.

\begin{tabular}{|c|c|c|c|}
\hline \multirow{2}{*}{ Index Layer } & \multicolumn{3}{|c|}{ Monitoring Values } \\
\cline { 2 - 4 } & 1980 s & 1990 s & 2000 s \\
\hline Estuary runoff index (\%) & 18 & 44 & 3 \\
\hline $\begin{array}{c}\text { Minimum ecological flow } \\
\text { guarantee rate (\%) }\end{array}$ & 85 & 77 & 54 \\
\hline Annual runoff change rate (\%) & 17 & 21 & 24 \\
\hline $\begin{array}{c}\text { Sediment transport change } \\
\text { rate (\%) }\end{array}$ & 82 & 88 & 97 \\
\hline Lateral stability index & 0.45 & 0.56 & 0.28 \\
\hline $\begin{array}{c}\text { Longitudinal connectivity } \\
\text { index }\end{array}$ & 0.44 & 0.64 & 0.98 \\
\hline $\begin{array}{c}\text { Water quality compliance rate } \\
\text { (\%) }\end{array}$ & 74 & 58 & 59 \\
\hline Phytoplankton Shannon index & 3.15 & 2.98 & 3.23 \\
\hline Vegetation index (\%) & 70 & 65 & 63 \\
\hline $\begin{array}{c}\text { Rate of water loss and soil } \\
\text { erosion (\%) }\end{array}$ & 63 & 57 & 49 \\
\hline Wetland preservation rate (\%) & 75 & 76 & 58 \\
\hline $\begin{array}{c}\text { Flood control guarantee rate } \\
(\%)\end{array}$ & 68 & 70 & 74 \\
\hline $\begin{array}{c}\text { Water supply guarantee rate } \\
(\%)\end{array}$ & 70 & 80 & 63 \\
\hline
\end{tabular}

\section{Water Quality Data}

Daily water quality monitoring data from 1988 to 2010 and corresponding water quality objectives of five monitoring stations (Chengde, Pingquan, Taolinkou, Panjiakou Reservoir, and Daheiting Reservoir) were collected. Locations and water quality objectives of these monitoring stations have been preapproved by HWRC. Six monitoring items were collected, which include dissolved oxygen (DO), chemical oxygen demand (COD), ammonia nitrogen $\left(\mathrm{NH}_{3}-\mathrm{N}\right)$, total phosphorus (TP), arsenic (As), and volatile phenol (VLPH).

\section{Soil and Water Loss Data}

Soil and water loss data were monitored about every 10 years in this area, and the data of 1984, 1999, and 2011 were collected from Haihe Basin Soil and Water Conservation Monitoring Center (HSWCMC).

\section{Aquatic Biological Data}

Phytoplankton information of 1987-88, 2001-02, and 2009 were collected from HWRC.

\section{Land Use Data}

The clear TM remote sensing images that contain data from 1985, 1995, and 2004 were received from the International Scientific Data Service Platform (ISDSP).

\section{Water Supply and Flood Control Data}

Water supply and flood control data from 1980 to 2010 were collected from HWRC.

Because some data were monitored for about 10 years, the 1980s, 1990s, and 2000s were selected as the evaluating time. Each index value of each period can be seen in Table 4.

\section{Results}

By employing the method mentioned above, as well as the data collected in the 1980s, 1990s, and 2000s, the health states were evaluated and the final results were provided in Fig. 2.

As can be seen in Fig. 2, Luanhe River's RHI decreased during these decades, indicating that the Luanhe River ecosystem became less healthy during the past 30 years. According to Table 3, the Luanhe was in a sub-healthy state in the 1980s and in an unhealthy state in the 1990s 


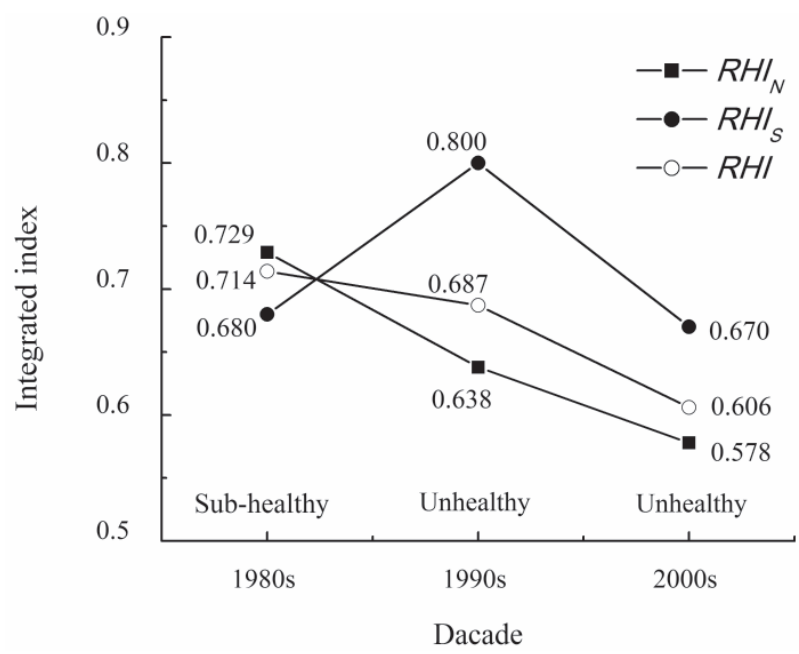

Fig. 2. Health evaluation results of the Luanhe River.

and the 2000s. In the aspect of its subsystem, the natural function integrated index was also on the decline during these decades. This showed that its natural function subsystem was becoming worse and worse, because the indexes, estuary runoff index, minimum ecological flow guarantee rate, sediment transport change rate, longitudinal connectivity index, and water quality compliance rate were decreasing almost annually. The social service function integrated index increased at first but later decreased. This indicates that its social function subsystem became better in the 1990s than in the 1980s, then worse in the 2000 s, because the index and water supply guarantee rate (which accounts for a relatively large weight) became better in the 1990s, then worse in the 2000s.

\section{Discussion}

From these results we can easily find that the main factors leading to the Luanhe's health deterioration are estuary runoff index, minimum ecological flow guarantee rate, sediment transport change rate, longitudinal connectivity index, water quality compliance rate, and water supply guarantee rate. And the underlying reasons for such phenomena include two aspects: human activity and climate change.

Both rainfall estuary runoff double mass curve of Luanhe River (Fig. 3a) and total storage capacity of large and medium-sized reservoirs from 1955 to 2010 in the Luanhe River (Fig. 3b) had been analyzed. From Fig. 3a), we can find that the curve is almost a rising straight line before 1979, and the curve deviates from the original trend after 1979. The existing inflexion point of the curve indicates that Luanhe runoff is strongly interfered with by human activities after 1979. Otherwise, there are another two inflexion points: 1994 and 1998. Fig. 3b) showed that the Luanhe's major reservoirs include the Panjiakou (built in 1979; utilizable capacity $1.95 \times 10^{9} \mathrm{~m}^{3}$ ), Daheiting (built in 1986; utilizable capacity $2.01 \times 10^{8} \mathrm{~m}^{3}$ ), and Taolinkou (built in 1998;
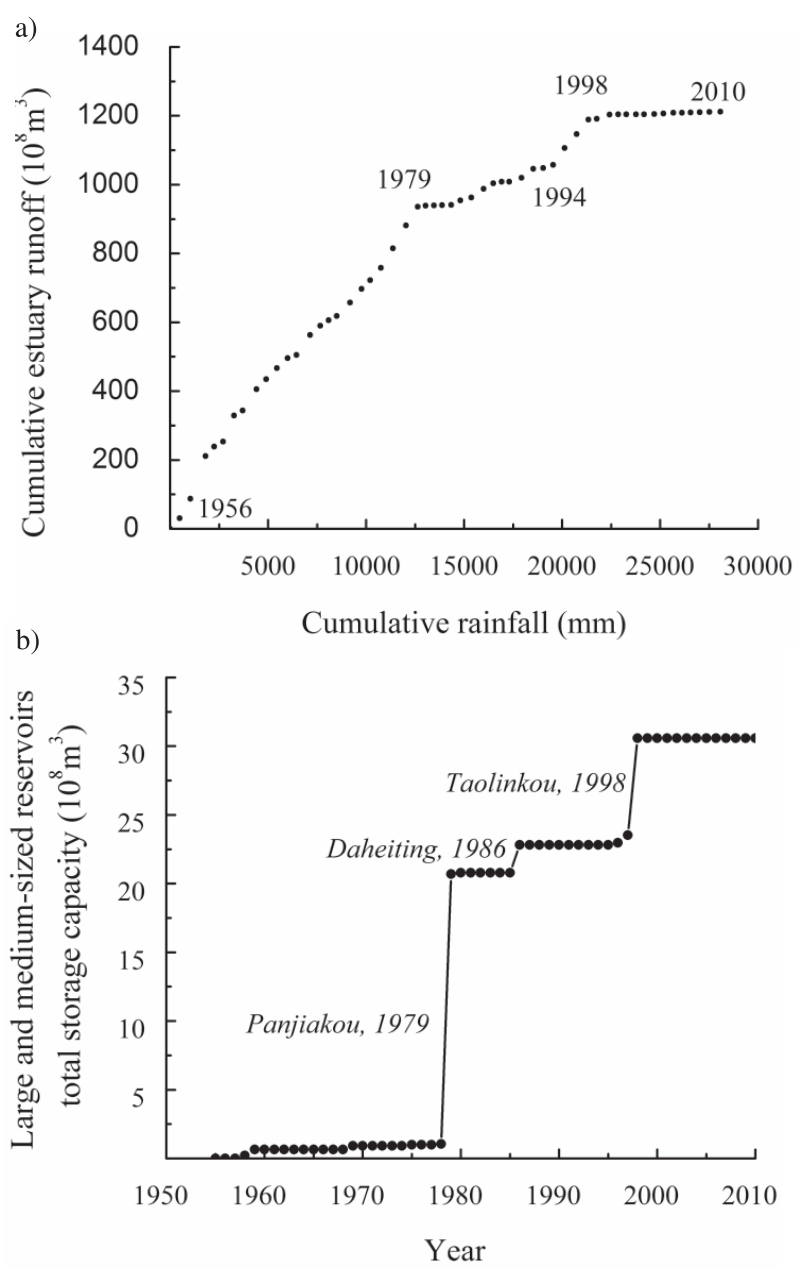

Fig. 3. Effect of large and medium-sized reservoirs on the Luanhe River: a) rainfall-estuary runoff double mass curve of the river and b) total storage capacity variation curve of large and medium-sized reservoirs in the river.

utilizable capacity $7.06 \times 10^{8} \mathrm{~m}^{3}$ ) reservoirs. And the years 1979 and 1998 are consistent with two inflexion points in Fig. 3a. This phenomenon could reflect that the water conservation projects' building and operating has influenced the ecosystem and made the Luanhe unhealthy over the past 30 years. The runoff and sediment of the river are declining, and the connectivity of water flow, material flow, energy flow, and information flow have all been destroyed by the construction of these dams. This inference can also be verified by Liu with the indicators of hydrological alteration (IHA) program based on the range of variability approach (RVA) [36]. The degree of ecological impact by each dam is as follows: Panjiakou $>$ Taolinkou $>$ Shandianhe (built in 1958; utilizable capacity $1.47 \times 10^{7} \mathrm{~m}^{3}$ ), and the index of IHA river flow change in Panjiakou Reservoir is 0.88 , which belongs to serious impact level.

So water conservation project building and operating is an important factor that cannot be ignored when analyzing the Luanhe's health degradation. Another reason is wastewater emissions. The wastewater emission of urban industrial, household, and agricultural production has now 
reached 4.5 tons per year, which is twice of that in the 1980s. Huge sewage volume plus a continuous reduction of the flow have made the middle and lower reaches of the Luanhe seriously polluted, which has intensified the river's ecosystem degradation.

In addition, the expansion of urban built-up areas over exploitation of groundwater and some other irrational human activities have also intensified the river's health degradation to some degree. Urban built-up area expansion has brought many pollutants and changed the watershed's underlying surface, which has resulted in the changes of the natural water cycle and the ecological balance of the river basin. Over-exploitation of underground water is another factor that has intensified the degradation. The annual average amount of shallow groundwater resources in the lower reaches of the river is $8.9 \times 10^{8} \mathrm{~m}^{3}$, and the exploiting amount is $8.54 \times 10^{8} \mathrm{~m}^{3}$. The exploiting rate of groundwater is up to $96.0 \%$ [37]. Strong water resource development activities have altered the relationship between surface water and groundwater, which is a threat to the ecological environment of the river.

\section{Conclusions}

Much is involved in a health assessment of a river ecosystem. To better reflect the Luanhe's characteristics, the index system of Luanhe River ecosystem health has been established. It includes two subsystems: its natural function subsystem and its social service function subsystem. The weight values were determined by expert evaluation method and the assessment standards were given on the basis of many existing standards. To solve the incompatibility and conflicts between the various conditions of different indexes and the actual river health status, the fuzzy matter-element extension assessment model was built and successfully applied to analyze the Luanhe River ecosystem during the past three decades.

Luanhe River's $R H I$ is decreasing during these three decades and the river is in an unhealthy state at present. The natural function of the Luanhe River became worse and worse, as demonstrated by the following indexes: estuary runoff index, minimum ecological flow guarantee rate, sediment transport change rate, longitudinal connectivity index, and water quality compliance rate. The social function got better in the 1990s over the 1980s, and then became worse in the $2000 \mathrm{~s}$, which coincided with the variation trend of its water supply guarantee rate.

The reasons for the Luanhe's health degradation have been analyzed. Among them, water conservation project building and operating is the most important influence factor. Wastewater emissions, the expansion of urban built-up areas, over-exploitation of underground water, and some other irrational human activities also have intensified the Luanhe River's health degradation to a certain extant. In order to improve the health state of the Luanhe River ecosystem, the following countermeasures are put forward:
1) Optimize operating rules of water conservation projects and increase ecological flow in the midstream and downstream of the Luanhe to meet the aquatic ecosystem ecological water requirements.

2) Bring the total amount of pollutants under control in the Luanhe. And some sewage treatment plants are also needed to be built to improve the management capacity of river pollution discharge.

3) Build water-saving society in the Luanhe River Basin and reduce the exploitation of groundwater.

4) Increase investment in ecological protection and basin management. On the one hand, increase funding of river wetland protection and strengthening scientific research in river ecosystem restoration, while on the other hand further straightening out management relations, perfecting related laws and regulations, strengthening river ecological protection publicity and education, and raising ecological awareness and public participation enthusiasm [38].

In conclusion, FMEAM is feasible as a scientific method, and reasonable in conclusion, which can be applied to river ecosystem health assessment research, and the stakeholders and policy makers can understand the health of the river easily according to $R H I$, which can help them to make correct decisions in the future, and to know how to improve its health state by analyzing its subsystem or a very specific index. Otherwise, our work can also provide a basis for the mechanism study of river evolution and river integrated management and restoration.

\section{Acknowledgements}

This research was supported by project Nos. 41471014 and 51409091 from the National Natural Science Foundation of China, project No. 2016003 sponsored by the Water Resources Department of Jiangsu Province, project No.201101017 sponsored by the Ministry of Water Resources of China, and project No. 2014B34714 supported by the Fundamental Research Funds for the Central Universities of China.

\section{References}

1. KARR J.R. Defining and measuring river health. Freshwater Biology, 41 (2), 221, 1999.

2. XU W., DONG Z., FU X., TAN J., LIU Q., DU F. Early warning of river ecosystem health based on BP artificial neural networks. Journal of Hohai University (Natural Sciences), 43 (1), 54, 2015.

3. MALVEIRA V.T.C., ARAUJO J.C.D., GUNTNER A. Hydrological impact of a high-density reservoir network in semiarid northeastern Brazil. Journal of Hydrologic Engineering, 17 (1), 109, 2012.

4. YU M., LI Q., LU G., CAI T., XIE W., BAI X. Investigation into the impacts of the Gezhouba and the Three Gorges Reservoirs on the flow regime of the Yangtze River. Journal of Hydrologic Engineering, 18 (9), 1098, 2013. 
5. SHRIVASTAVA G.S. Estimation of sustainable yield of some rivers in Trinidad. Journal of Hydrologic Engineering, 8 (1), 35, 2003.

6. BEECHIE T., IMAKI H., GREENE J., WADE A., WU H., PESS G., RONI P., KIMBALL J., STANFORD J., KIFFNEY P., MANTUA N. Restoring salmon habitat for a changing climate. River Research and Applications, 29 (8), 939, 2013.

7. LI Q., YU M., LU G., CAI T., BAI X., XIA Z. Impacts of the Gezhouba and Three Gorges Reservoirs on the sediment regime in the Yangtze river, china. Journal of Hydrology, $\mathbf{4 0 3}$ (3-4), 224, 2011.

8. HE Y., WANG F., TIAN P., MU X., GAO P., ZHAO G., WU Y. Impact assessment of human activities on runoff and sediment of Beiluo River in the Yellow River based on paired years of similar climate. Polish Journal of Environmental Studies, 25 (1), 121, 2016.

9. MATYSIK M., ABSALON D., RUMAN M. Surface water quality in relation to land cover in agricultural catchments (Liswarta River Basin case study). Polish Journal of Environmental Studies, 24 (1), 175, 2015.

10. ZHAI X., ZHANG Y., WANG X., XIA J., LIANG T. Nonpoint source pollution modelling using soil and water assessment tool and its parameter sensitivity analysis in Xin'anjiang Catchment, China. Hydrological Processes, 28 (4), 1628, 2014.

11. BARTON D.N., SALORANTA T., MOE S.J., EGGESTAD H.O., KUIKKA S. Bayesian belief networks as a metamodelling tool in integrated river basin management pros and cons in evaluating nutrient abatement decisions under uncertainty in a Norwegian river basin. Ecological Economics, 66 (1), 91, 2008.

12. NORRIS R.H., THOMS M.C. What is river health? Freshwater Biology, 41 (2), 197, 1999.

13. ALEKSANYAN A., KHUDAVERDYAN S., VASEASHTA A. Modeling river ecosystem vulnerability assessments due to climate change: Case study of Armenia. Polish Journal of Environmental Studies, 24 (2), 871, 2015.

14. KARR J.R. Assessment of biotic integrity using fish communities. Fisheries, 6 (6), 21, 1981.

15. DANIEL H. CHRISTIAN K.F., OTTO M. Cook book for the development of a Multimetric Index for biological condition of aquatic ecosystems: Experiences from the European AQEM and STAR projects and related initiatives. Hydrobiologia, 566 (1), 311, 2006.

16. MUNNEA., PRAT N. Defining river types in a Mediterranean area: A methodology for the implementation of the EU Water Framework Directive. Environmental management, 34 (5), 711,2004

17. ROTT E., PIPP E., PFISTER P. Diatom methods developed for river quality assessment in Austria and a cross-check against numerical trophic indication methods used in Europe. Algological Studies, 110 (1), 91, 2003.

18. ZHAO Y., YANG, Z. Integrative Fuzzy Hierarchical Model for river health assessment: A case study of Yong River in Ningbo City, China. Communications in Nonlinear Science and Numerical Simulation, 14 (4), 1732, 2009.

19. OLLIS D.J., BOUCHER C., DALLAS H.F., ESLER K.J. Preliminary testing of the Integrated Habitat Assessment System (IHAS) for aquatic macroinvertebrates. African Journal of Aquatic Science, 31 (1), 1, 2006.

20. SHANG S., WANG H. Assessment of impact of water diversion projects on ecological water uses in arid region. Water Science and Engineering, 6 (2), 119, 2013.

21. JAIN S.K. Assessment of environmental flow requirements. Hydrological Processes, 26 (22), 3472, 2012.
22. THARME R.E. A global perspective on environmental flow assessment: Emerging trends in the development and application of environmental flow methodologies for rivers. River Research and Applications, 19 (5-6), 397, 2003.

23. BLAZER V.S., IWANOWICZ D.D., WALSH H.L., SPERRY A.J., IWANOWICZ L.R., ALVAREZ D.A., BRIGHTBILL R.A., SMITH G., FOREMAN W.T., MANNING R. Reproductive health indicators of fishes from Pennsylvania watersheds: Association with chemicals of emerging concern. Environmental monitoring and assessment, 186 (10), 6471, 2014.

24. YANG Y, LI Y, FAN Y., ZHANG J. Impact of water and sediment discharges on subaqueous delta evolution in Yangtze Estuary from 1950 to 2010. Water Science and Engineering, 7 (3), 331, 2014.

25. TROYER N.D., MERETA S.T., GOETHALS P.L.M, BOETS P. Water quality assessment of streams and wetlands in a fast growing east African city. Water, 8 (4), 123, 2016.

26. KOSE E., TOKATLI C., CICEK A. Monitoring stream water quality: a statistical evaluation. Polish Journal of Environmental Studies, 23 (5), 1637, 2014.

27. YU Z., YANG T., SCHWARTZ F.W. Water issues and prospects for hydrological science in China. Water Science and Engineering, 7 (1), 1, 2014.

28. YAN D., WANG G., WANG H., QIN T. Assessing ecological land use and water demand of river systems: A case study in Luanhe River, north China. Hydrology and Earth System Sciences, 16 (8), 2470, 2012.

29. XIA T., ZHU W., XIN P., LI L. Assessment of urban stream morphology: an integrated index and modelling system. Environmental monitoring and assessment, 167 (1-4), 448, 2010.

30. WU W., XU Z., YIN X., ZUO D. Assessment of ecosystem health based on fish assemblages in the Wei River Basin, China. Environmental monitoring and assessment, 186 (6), 3701, 2014.

31. CHE Y., YANG K., WU E., SHANG Z., XIANG W. Assessing the health of an urban stream: A case study of Suzhou Creek in Shanghai, China. Environmental monitoring and assessment, 184 (12), 7425, 2012.

32. XIA J., LIN L., LIN J., NEHAL L. Development of a GISbased decision support system for diagnosis of river system health and restoration. Water, 6 (10), 3136, 2014.

33. LIU Q., DONG Z., XU W., FU X., TAN J., CHEN X., YANG G. Health assessment of Luanhe River based on Fuzzy Matter-element Model. Water Resources and Power, 32 (9), 47, 2014

34. RAIKHMAN É.P. Expert method of instrument quality evaluation. Measurement Techniques, 13 (11), 1760, 1970.

35. CAI W., GUO K., HUANG Y. Matter element analysis and value engineering. Journal of Guangdong University of Technology, (1), 7, 1984.

36. LIU J., YOU X., SHI X., BAO K., MENG B. Hydrological and ecological effects of dams in Luanhe River Basin. Water Resources Protection, 32 (1), 23, 2016.

37. LU X., WANG G., CHEN N., LIU S. Hydrological effects of water resources development and its eco-environmental response in Luanhe River Basin. Environmental Protection Science, 40 (1), 18, 2014.

38. REN L., LIU J., Ni, J., XIANG X. Health evaluation of a lake wetland ecosystem based on the TOPSIS method. Polish Journal of Environmental Studies, 23 (6), 2190, 2014. 
